IZA DP No. 8810

A Tacit Monetary Policy of the Gulf Countries: Is There a Remittances Channel?

Ali Termos

Ismail Genc

George Naufal

January 2015 


\title{
A Tacit Monetary Policy of the Gulf Countries: Is There a Remittances Channel?
}

\author{
Ali Termos \\ American University of Beirut \\ Ismail Genc \\ American University of Sharjah \\ George Naufal \\ Timberlake Consultants \\ and IZA
}
Discussion Paper No. 8810
January 2015

IZA
P.O. Box 7240
53072 Bonn
Germany

Phone: +49-228-3894-0

Fax: +49-228-3894-180

E-mail: iza@iza.org

\begin{abstract}
Any opinions expressed here are those of the author(s) and not those of IZA. Research published in this series may include views on policy, but the institute itself takes no institutional policy positions. The IZA research network is committed to the IZA Guiding Principles of Research Integrity.

The Institute for the Study of Labor (IZA) in Bonn is a local and virtual international research center and a place of communication between science, politics and business. IZA is an independent nonprofit organization supported by Deutsche Post Foundation. The center is associated with the University of Bonn and offers a stimulating research environment through its international network, workshops and conferences, data service, project support, research visits and doctoral program. IZA engages in (i) original and internationally competitive research in all fields of labor economics, (ii) development of policy concepts, and (iii) dissemination of research results and concepts to the interested public.
\end{abstract}

IZA Discussion Papers often represent preliminary work and are circulated to encourage discussion. Citation of such a paper should account for its provisional character. A revised version may be available directly from the author. 
IZA Discussion Paper No. 8810

January 2015

\section{ABSTRACT}

\section{A Tacit Monetary Policy of the Gulf Countries: Is There a Remittances Channel?}

The strong economic ties between the GCC economies and the U.S. are manifested in three ways: currency peg, coupling of monetary policy, and the adoption of the U.S. dollar as the trading currency for oil. This paper examines how these dynamics result in a misalignment of the U.S. monetary policy with the business cycles of the GCC economies. The study shows how the staggering amount of remittances outflow of the GCC economies plays a stabilizing role as a tacit monetary policy tool. Incorporating remittances in the money demand equation results in a more robust model than otherwise. We further find that the effect of the Federal Funds rate on money demand in these countries diminishes in significance during the period of oil boom between 2002 and 2009. However, the transmission effect of the recession periods in the U.S. into the demand for money in the GCC countries is not statistically significant.

JEL Classification: F24, N15

Keywords: remittances, inflation, monetary policy, GCC

Corresponding author:

George Naufal

Timberlake Consultants

B3 Broomsleigh Business Park

Worsley Bridge Road

London SE26 5BN

United Kingdom

E-mail: georgenaufal@timberlake.co.uk 


\section{Introduction and motivation}

Studies on remittances have grown significantly in the last two decades due to the increased interest in these monetary flows. This is mainly driven by the increasing amount of remittances and their economic consequences on the recipient economies. Remittance inflows outweigh the value of the official aid transfers and that of the net private capital transfers for several countries (De Haas, 2007). Empirically, the economic ramifications of remittances have effects on exchange rates (Amuedo-Dorantes and Pozo, 2004), labor supply (Amuedo-Dorantes and Pozo, 2006), economic growth (Chami et al, 2005; Giuliano and Ruiz-Arranz, 2009; and Gupta et al 2009), schooling decisions (Edwards and Ureta; 2003), and income inequality and poverty (Docquier and Rapoport, 2003; Adams and Page, 2005).

While most research on remittances investigates the consequences of these monetary transfers on the recipient economies, little is known of the effects of remittances on the remitting economies. The main reason behind this oversight is that the size of remittances was never significant whether in absolute sum or as a percentage of the Gross Domestic Product (GDP) of the remitting economy. In this regard, the Gulf Cooperation Council (GCC) countries present an emerging opportunity to study the effects of remittances on the remitting economies given that these countries rank among the top remitters in the world. ${ }^{1}$ For instance, the official monetary transfers from Saudi Arabia reached 27 billion USD in 2010 placing it second to the United States (U.S.) (World Bank, 2011). Kuwait and Oman both rank among the top twelve remitting countries with more than 18 billion USD in outward remittances in $2010 .^{2}$

As a ratio of GDP, the GCC countries also rank among the top remitting countries in the world. Kuwait, Oman, Bahrain and Saudi Arabia rank the fourth, sixth, eighth, and eleventh, respectively, with shares of outward remittances to GDP ranging from 6\% to $9 \%$. For Qatar this ratio was 
estimated to be 11\% in 2009 (Endo and Afram, 2011). In order to assess the impact of the outflow of remittances on the GCC's monetary policy, one cannot ignore the strong economic ties between the GCC countries and the U.S. These ties are identified in three main channels: pegging of the GCC currencies to the U.S. dollar, coupling of both the U.S. monetary policy and that of the GCC countries, and the adoption of the U.S. dollar as the official trading currency for oil in the international market.

In theory, while a rise in energy prices, mainly the price of oil, is expected to result in economic downturn in the U.S., it would boost the GCC economies. The Federal Reserve Bank therefore, will be anticipated to engage in interest rate cut to curb an expected recession. As the GCC economies are closely tied to the Federal Reserve Bank actions, they follow its policy by cutting interest rates at home to avoid any appreciation of their domestic currencies. The cut in interest rate would exacerbate inflation in the expanding GCC economies and send it to a higher level than desired. Furthermore, while the Federal Reserve Bank conducts open market purchase to pour money in the U.S. economy to enhance economic activities, the GCC economies need to be engaged in an open market sale to slow down their economies and attenuate the expected rise in inflation. However, given the lack of an operational governmental bond market in this regional economy in addition to a less autonomous monetary policy, the staggering amount of remittances fleeing the GCC economies during economic upturns seems to play a stabilizing role as a tacit monetary policy tool. We show that these remittances are able to mitigate the inflationary pressure that is induced by the increase in the price of oil. Figure (1) shows a negative correlation between the Federal Funds Rate (FFR) and the spot oil price in and around recession times in the U.S. except perhaps for the last two recessions of 2001 and 2008. During these two recessions, both the 
spot oil price and FFR decline. However, between 2002 and 2008 most changes in oil price are positive and oil revenue peaked during that period. ${ }^{3}$

This paper contributes to the literature on remittances by examining the monetary effects of outward remittances on the remitting economy. In particular, we investigate the impact of these transfers on the conduct of monetary policy in the GCC countries. Remittances outflow eases the inflationary pressure that is induced by excessive oil revenue enjoyed by these economies during the oil-boom period of 2002-2009. Therefore, remittance outflows play a stabilizing role as a tacit monetary policy tool for the GCC countries similar to the open market sale of government bonds.

We examine a money demand equation for the GCC countries that is more robust when remittances are controlled for than in a classic model. We find that the effect of the Federal Funds rate on money demand in these countries diminishes in significance during the period of oil boom between 2002 and 2009. However, the transmission effect of the recession periods in the U.S. into the demand for money in the GCC countries is not significant.

The paper proceeds as follows. In Section II we present an overview of the dynamics of remittances in the GCC region and their international relevance. In Section III we examine how this outward leakage of money proves to be an integral part of the determinants of money demand in this region. In Section IV we draw some concluding remarks and policy implications.

\section{The dynamics of remittances outflow in the GCC economies}

In the last two decades and up until the onset of the financial crisis of 2008, global remittances have been consistently increasing (Ruiz and Vargas-Silva, 2009). For many developing economies remittances outweigh foreign aid and Foreign Direct Investment (FDI) in dollar amount (Connell and Brown 2004; De Haas, 2006; Heilmann 2006; Chami et al. 2006). The significant rise in the stock of international migrants associated with a declining cost of transferring money spurred a 
remarkable surge in the international flow of remittances (Ratha, 2007). The World Bank estimates the remittance flows at more than 440 billion USD in $2010 .{ }^{4}$ These large sums of monetary transfers have raised a keen interest in remittances among researchers and policy makers alike. However, the extant literature has only focused on the economic consequences of remittances on the recipient end and fell short on examining these effects on the remitting economies. The main reason for this paucity is that remittances outflow was never a sizeable ratio of GDP of the remitting economy. Therefore, the story of the GCC economies is telling. While most remitting countries are OECD members whereby remittances constitute a small proportion of their respective GDPs, remittances outward from the GCC countries are of significant ratio of major macroeconomic indicators, particularly GDP.

[INSERT TABLE 1 Panels A and B ABOUT HERE]

Panels A and B of Table 1 present an overview of the importance of remittances outflow for the GCC economies. In 2010, more than 63 billion USD were transferred from the GCC with an average GDP share of 7.5\%. In Kuwait and Qatar, remittances outflow per capita surpassed 4,000 USD while this value jumps to more than 6,000 USD for Kuwait, Oman, and Qatar when limiting the population to foreign workers. The mean of remittances outflow per capita is around 2,500 USD for total population and more than 4,500 USD for foreign population. To put these figures in perspective, the largest remittances per capita for recipient countries were 1,407 USD for Lebanon in 2007 (UN Human Development Report, 2009). ${ }^{5}$ The remittances per capita for the other recipient countries are less than 1,000 USD. Further, and as shown in Panel B of Table 2, remittances outflow constitutes a large share of four main macroeconomic variables for the GCC countries: GDP, exports, imports, and consumption. For instance, while the mean remittances 
outflow is almost $7.5 \%$ of GDP in the GCC countries, the ratio of remittances to the other variables is above $10 \%$.

Remittances outward from the GCC region have been mainly fuelled by a large influx of foreign workers. The strong economic growth and the relative political stability that the GCC economies have experienced in the last two decades lured a large number of workers from all over the world. The mean proportion of the foreign population in the Gulf is more than 50\%, with Qatar and UAE reporting more than $70 \%$ of their population as expatriates (Panel A of Table 1). ${ }^{6}$ The rising demand for foreign labor came as a result of the mega projects that were undertaken by the GCC governments, accompanied by a major revamp of infrastructure. These projects are mostly funded by oil receipts. ${ }^{7}$

Three additional factors contribute to this dramatic surge in remittances outflow from the GCC countries. First, foreign workers cannot obtain local citizenship in any of the GCC countries, irrespective of the length of their residency in these countries. Consequently, foreign workers and particularly blue-collar laborers who come mainly from less developed nations, have no incentive to reside in the Gulf permanently. ${ }^{8}$ This restriction on naturalization renders the Gulf as a transient destination whereby expatriates are compelled to remit money to prepare for their eventual return to their home countries. Second, foreigners are not permitted to own property in all six GCC countries. This restriction on property ownership crowds out expatriate savings and encourages them to send money to buy residential or commercial real estate in their home countries. Finally, the majority of low-skilled and blue-collar workers (i.e. most construction workers) are not allowed to bring in their families with them, let alone the fact that it is prohibitively costly for them to do so even if they are allowed to. This restriction further drives them to send most of their income home to support their dependents. ${ }^{9}$ 
All these factors combined make the GCC region one of the top remitters in the world. ${ }^{10}$ Therefore, the GCC economy presents a unique and intriguing case to examine the effects of remittances outflow on the remitting economy, especially when these monetary outflows comprise a relatively higher proportion of the GDP of the remitting economy.

We now turn to discuss the response of the GCC economies to a U.S. interest rate reduction. Suppose that the Federal Reserve Bank engages in a monetary policy expansion by cutting interest rate. The tandem of monetary policy of the GCC and that of the U.S. requires that the GCC countries follow suit in cutting interest rates. Naturally, this would boost investment and consumption in the latter countries, resulting in an economic expansion in these economies. Also, the increase in the price of oil would translate into a higher inflow of dollars to the GCC. While these dollar amounts are converted into the domestic currencies, leading to higher levels of money stock, aggregate demand shifts outward even further. As the income level in the economy increases, outward remittances are expected to reach higher levels as foreign workers (expatriates) remit more money to their respective home countries. That exerts additional pressure on the domestic currency to be converted into dollars, for remittances are usually sent in U.S. dollars. Thus, the reduction in the money stock pushes aggregate demand down. The final price-income equilibrium also depends on international prices. ${ }^{11}$ This is because, as small open economies, the GCC countries are more of price takers in the global market. The next section examines the remittances outflow channel of monetary policy in more details.

\section{Examining the remittances channel of monetary policy in the GCC countries}

Given the importance of remittances in the GCC economies and in an effort to examine whether the effect of remittances on this region's economic performance is not just transitory but rather structural, one needs to gauge the potential long-run effect of these monetary outflows on 
the whole economy. To this end, we carry out a cointegration analysis for two different moneydemand models, one that includes remittances and another that does not. More specifically, we test the cointegration property of the monetary policy in the GCC economies according to the following specification of aggregate money demand equations:

$$
\begin{aligned}
& M_{i t}=\beta_{0}+\beta_{1} M_{i t-1}+\beta_{2} Y_{i t}+\beta_{3} R_{t}+\varepsilon_{i t} \\
& M_{i t}^{*}=\gamma_{0}+\gamma_{1} M_{i t-1}^{*}+\gamma_{2} Y_{i t}+\gamma_{3} R_{t}+\varepsilon_{i t}
\end{aligned}
$$

Equation (1) refers to the benchmark aggregate money demand for the GCC countries. $M_{i t}$ is the change in the log of real money for country $i$ at time $t$, it is defined as "money plus quasimoney in USD million" transformed to real terms by the GDP deflator, where 2005 is the base year. Real GDP growth is given by $Y_{i t}$. The change in FFR is given by $R_{t}$. The justification for the use of FFR for the GCC interest rates is based on the assumption of interest rate parity. ${ }^{12}$ Equation (2) presents the change in the log of the difference between real money and real remittances:

$$
M_{i t}^{*}=\log \left(\frac{M_{i t}}{P_{i t}}-\frac{C_{i t}}{P_{i t}}\right)
$$

Where $C_{i t}$ is remittances outflow, and $P_{i t}$ is the GDP deflator. That is, real money growth is positively related to real GDP growth, $\left(\beta_{2}>0\right)$, and negatively related to changes in nominal interest rate, $\left(\beta_{3}<0\right)$. Alternatively, equation (2) presents real money in excess of remittances, or what we refer to as net money, which is the actual amount of money remaining in the remitting country once remittances are repatriated. Analogously, net money is positively related to real GDP, $\left(\gamma_{2}>0\right)$, and negatively related to nominal interest rate, $\left(\gamma_{3}<0\right)$.

We test these two models for the six GCC countries for the period of $1970-2012$. The data on money and GDP deflator are obtained from the International Financial Statistics (IFS) of the IMF. Data on remittances come from the World Bank for all countries except for the UAE and 
Qatar, whose data are obtained from the Arab Monetary Fund database. FFR data is collected from the Federal Reserve Bank of St. Louis. Table 2 presents some descriptive statistics to provide an overview of the economic conditions of this region. Obviously, this is an affluent region with a sizable leakage in the economy in the form of remittances. Inflation is usually under check.

[INSERT TABLE 2 ABOUT HERE]

Given that the GCC countries peg their currencies to the U.S. dollar, the fixed exchange rate regime should provide a transmission mechanism from the interest rate of the anchor country to that of the adopting country (Bluedorn and Bowdler 2006; Obstfeld et al 2005). ${ }^{13}$

Next, we run a battery of cointegration tests using Pedroni (1999 and 2004). ${ }^{14}$ We include a linear trend and an intercept in the data, but we do not impose a trend in the cointegration equation. We start by testing the cointegration among, $M, Y$, and $R$. The Pedroni (Panel v) and Augmented Dickey-Fuller (ADF) tests support the lack of cointegration among real money growth, real income growth and interest rate shifts. Thus, we conclude that the monetary policy dynamics in the GCC countries cannot be consistently described by this relationship. Then we carry out the cointegration tests among, $M^{*}, Y$, and $R$. Though there are a few exceptions, we can conclude that the Pedroni tests tend to reject the lack of cointegration among these three variables, supporting our initial proposition that a model with remittances is a better fit for the GCC economy. ${ }^{15}$

Our findings point at an economic environment better described by equation (2) as opposed to equation (1). In other words, the fit model of monetary policy in the GCC countries should incorporate remittances into the money demand equation. Money defined as such, can be analyzed as a function of real GDP growth and interest rate. Therefore, to estimate the coefficients of the long-run relationship among these variables, we use a GMM dynamic panel data model as 
developed by Arellano and Bover (1995) and Blundell and Bond (1998). ${ }^{16}$ The results are shown in Tables 3 and 4.

[INSERT TABLES 3 AND 4 ABOUT HERE]

Based on these results, we can present the estimated monetary relationship for the GCC economy as given by:

$$
M_{i t}^{*}=0.666+0.986 M_{i t-1}^{*}+1.028 Y_{i t}-0.037 R_{t}
$$

All variables are statistically significant. ${ }^{17}$ The estimation shows that a one percent increase in real income would lead to 1.028 percent increase in the revised money demand. Likewise, an increase in the interest rate would negatively affect money demand. More specifically, a one basis point increase in interest rate would lead to an approximate decline of 3.7 basis points in the revised growth in money demand. Additionally, as shown in Table 3, we start by estimating the baseline model as in equation (2), and then we introduce a dummy variable for the "Volcker experiment" during the years 1978-1982 that aimed at stabilizing inflation rather than the output gap (column 2). However, the results show that there is no statistical significance of this dummy variable on money demand in the GCC during that period. In another model, we introduce a dummy variable for the recession dates in the U.S. as identified by the National Bureau of Economic Research (NBER) (column 3). Again, no statistical significance for this variable is found. In Table 4 we control for these events by splitting the data rather than introducing dummy variables. In one specification, we split the data into two time periods: pre-Volcker (i.e. pre 1979) and post-Volcker years (i.e. post 1982). The result remain qualitatively identical to the previous one with the exception of the effect of the change in FFR on money demand; in the pre-Volcker experiment the effect is twice as large as in the post-Volcker experiment. Given the lack of data on remittances for most of the GCC countries for the 1970s and 1980s, and the fact that remittances were not a 
significant proportion of their respective GDPs during that period, it is expected to see this large effect when FFR peaked to its historical record during that period. Finally, we control for the period 2002-2009 which witnessed a boom in the oil revenue for the GCC countries. Here the results are very similar to the ones reported in the baseline model but again with the exception of the coefficient of GDP growth being the highest in this specification compared to the other estimations (column 3 of Table 4). However, the coefficient of the change in FFR is the smallest and least significant. These findings indicate that during this period, A 1\% rise in GDP increases the demand for money by $1.091 \%$ as compared to $1.028 \%$ for the entire period of study. However, a drop in the Federal Funds rate by a 1 basis point led to 2.45 basis points increase in the demand for money during the period of oil boom while this figure is 3.7 basis points for the entire sample. This clearly indicates that the rise of remittances that is associated with the oil boom has played a stabilizing role by mitigating the inflationary pressure in the GCC countries that otherwise might have been triggered by a rather higher demand for money.

\section{Concluding remarks}

Remittance outflows from the GCC economies represent a significant share of their GDP. These large outflows are mainly driven by high proportion of foreign labor force to total population and the legal restrictions on family reunification for most low-skilled foreign laborers, but also by high economic growth and unprecedented spikes in oil revenue in the last two decades. Unlike most studies on remittances, we investigate the impact of these monetary outflows on the remitting rather than on the recipient economies. The strong economic ties between the GCC region and the U.S. compel the former to closely follow the monetary policy stances of the latter. However, the two policies are not always aligned and remittances prove to attenuate the effect of interest rate variations in the U.S. on the GCC economies. 
This study examines how the staggering amount of remittances from the GCC economies during economic upturns plays a stabilizing role as a tacit monetary policy tool. This feature of remittances provides flexibility to the monetary policy making in the GCC region in the absence of fully developed capital markets. Empirically, we show that incorporating remittances in the money demand equation yields a statistically more robust model than otherwise. This robustness was exemplified in finding a long run cointegration among the main policy variables of the model.

How far one can generalize the claim that remittances mitigate inflationary pressure in the remitting country depends on various factors that distinguish the GCC economies from other remitting economies. First, the high ratio of outward remittances to GDP creates what we coin as a remittances channel through which inflation is mitigated. Second, the large influx of expatriates to the general population is a unique feature of the GCC economies and contributes to the mounting significance of remittance outflows. Third, the pegging of the domestic currencies to the U.S. dollar provides an interesting scenario where remittances seem to play an implicitly favorable role for the monetary policy efficacy in the GCC countries but also present a difficult challenge for their fiscal policy. 


\section{References}

Adams, R. and Page, J. (2005) "Do International Migration and Remittances Reduce Poverty in Developing Countries?” World Development, 33(10), 1645 - 1669.

Adams, R. (2009) "The Determinants of International Remittances in Developing Countries," World Development, 37 (1), 93 - 103.

Al-Raisi, A. H., S. Pattanaik, and A. Y. Al Raisi (2007) "Transmission Mechanism of Monetary Policy Under the Fixed Exchange Rate Regime of Oman," Central Bank of Oman Occasional Paper No. 2007-1.

Amuedo-Dorantes, C. and Pozo, S. (2004) "Worker's Remittances and the Real Exchange Rate: A Paradox of Gifts," World Development, 32, 1407-1417.

Amuedo-Dorantes, C. and S. Pozo (2006) "Migration, Remittances and Male and Female Employment Patterns," American Economic Review, 96 (2), 222 - 226.

Ann Colton, N. (2010) “The International Political Economy of Gulf Migration," Viewpoints Special Edition Migration and the Gulf Middle East Institute Viewpoints, (February), 34 - 36.

Arab Monetary Fund. Arab Monetary Fund Online Database. Accessed October 31, 2012. www.amf.org.ae.

Arellano, M., and O. Bover (1995) "Another look at the instrumental variable estimation of errorcomponents models," Journal of Econometrics 68: 29-51.

Bluedorn, J. and C. Bowdler (2006) "Open Economy Codependence: U.S. Monetary Policy and Interest Rate Pass-through," Economics Series Working Papers 290, University of Oxford, Department of Economics.

Blundell, R., and S. Bond (1998) "Initial conditions and moment restrictions in dynamic panel data models," Journal of Econometrics 87: 115-143.

Bova, E., (2012) "Interest Rate Spread in the GCC: the Role of Monetary Policy Intervention," IMF Working Paper.

Chami, R., Fullenkamp, C., Jahjah, S. (2005) “Are Immigrant Remittance Flows a Source of Capital for Development?” IMF Working Paper, 52(1), 55-81.

Chami, R., Cosimano, T., Gapen, M. (2006) "Beware of Emigrants Bearing Gifts: Optimal Fiscal and Monetary Policy in the Presence of Remittances," IMF Working Paper WP/06/61.

Connell, J., Brown, R. (2004) "The Remittances of Migrant Tongan and Samoan Nurses from Australia," Human Resources for Health 2(2). 
De Haas, H. (2006) "Migration, Remittances and Regional Development in Southern Morocco," Geoforum 37(4), 565-580.

De Haas, H. (2007) "Remittances, Migration and Social Development: A Conceptual Review of the Literature," Social Policy and Development Programme Working Paper Number 34.

Docquier, F. and Rapoport, H. (2003) "Remittances and Inequality: A Dynamic Migration Model," IZA Discussion Paper 808.

Edwards, A., Ureta, M. (2003) "International Migration, Remittances, and Schooling: Evidence from El Salvador," Journal of Development Economics 7, 429-461.

Endo, I. and G. Afram (2011) "The Qatar-Nepal Remittance Corridor. A World Bank Study," Working Paper, Washington DC: The World Bank.

Espinoza, R. and A. Prasad (2012) "Monetary Policy Transmission in the GCC Countries," IMF Working Papers WP/12/132, (May).

Giuliano, P., Ruiz-Arranz, M. (2009) "Remittances, Financial Development, and Growth," Journal of Development Economics 90, 144-152.

Gupta, S., Pattillo, C., and Wagh, S. (2009) "Effect of Remittances on Poverty and Financial Development in Sub - Saharan Africa," World Development 37 (1), 104 - 115.

Haderi,S. H. Papapanagos, P. Sanfey and M. Talka, (1999) "Inflation and Stabilisation in Albania," Post-Communist Economies 11(1), 127-141.

Heilmann, C. (2006) "Remittances and the Migration-Development Nexus-Challenges for the Sustainable Governance of Migration," Ecological Economics 59, 231-236.

International Monetary Fund (2012) International Financial Statistics Accessed October 31, 2012 http://elibrary-data.imf.org/.

Kandil, M. and H. Morsy (2011) "Determinants of Inflation in GCC," Middle East Development Journal 3 (2), 141 - 158.

Obstfeld, M., J. C. Stambaough, and A. M. Taylor (2005) "The Trilemma in History: Tradeoffs Among Exchange Rates, Monetary Policies, and Capital Mobility," The Review of Economics and Statistics MIT Press, vol. 87(3), 423-438, (August).

Ratha, D. (2007) "Leveraging Remittances for Development," MPI Policy Brief (June), www.worldbank.org/mena.nsf.

Ruiz, I., and Vargas - Silva, C. (2009) "To send or Not Send. That is the Question: A Review of the Literature on Remittances," Journal of Business Strategies 26 (1), 73 - 98. 
Naufal, G. and Vargas-Silva, C. (2010) "Migrant Transfer in the MENA Region: A Two Way Street in Which Traffic is Changing," Migration Letters 7(2), $168-178$.

Naufal, G. and I. Genc (2012) Expats and the Labor Force: The Story of the Gulf Cooperation Council Countries Palgrave Macmillan, New York.

Organization of the Petroleum Exporting Countries (OPEC) Annual Statistics Bulleting 2009 http://www.opec.org/opec_web/en/publications/202.htm.

Pedroni, P. L. (1999) "Critical Values for Cointegration Tests in Heterogeneous Panels with Multiple Regressors," Oxford Bulletin of Economics and Statistics 61 (4), 653 - 670.

Pedroni, P. L. (2004) "Panel Cointegration; Asymptotic and Finite Sample Properties of Pooled Time Series Tests with an Application to the Purchasing Power Parity Hypothesis," Econometric Theory 20, $597-625$.

Newey, W. K. and K. D. West (1987) “A Simple, Positive Semi-Definite, Heteroskedasticity and Autocorrelation Consistent Covariance Matrix,” Econometrica 55, 703-708.

Stock, J. H. and M. W. Watson (1993) “A Simple Estimator of Cointegrating Vectors in Higher Order Integrated Systems," Econometrica 61(4), 783-820.

United Nations (2009) Human Development Report 2009 Accessed October 31, 2012 https://mobiledevelopmentintelligence.com/metrics/123.

World Bank (2011) Migration and Remittances Fact Book 2011 Accessed October 31, 2012. http://data.worldbank.org/data-catalog/migration-and-remittances. 
Figure 1: Quarterly percentage changes (in basis points) of major variables

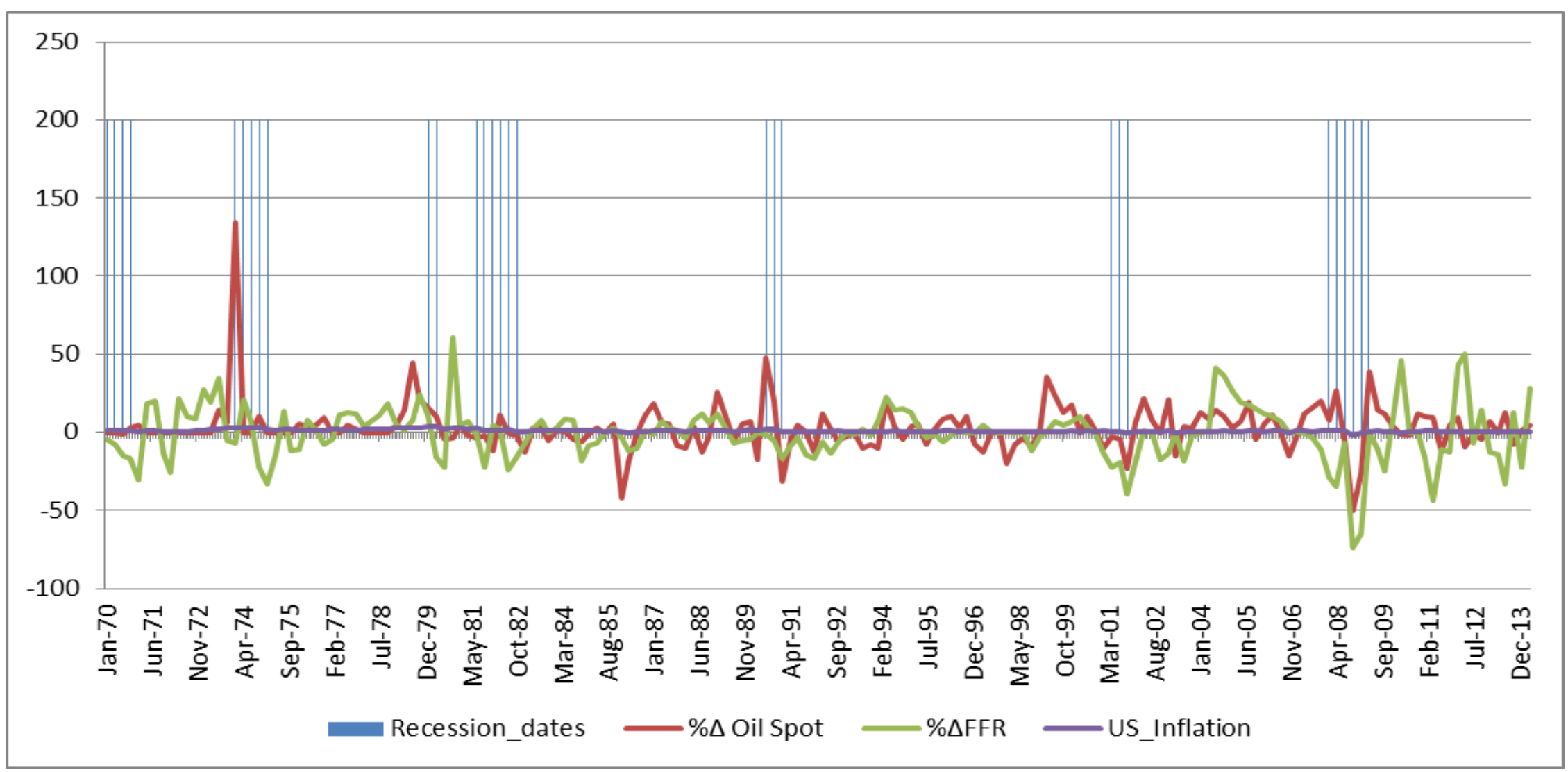


Table 1 - Panel A: Remittances Outflow from the GCC (2010) ${ }^{1}$

\begin{tabular}{cccccc}
\hline & $\begin{array}{c}\text { Remittance } \\
\text { Outflows } \\
\text { USD Billions }\end{array}$ & $\begin{array}{c}\text { Population } \\
\text { (Million) }\end{array}$ & $\begin{array}{c}\text { Percent of } \\
\text { Population as }^{\text {Migrants }}{ }^{3}\end{array}$ & $\begin{array}{c}\text { Remittances } \\
\text { per Capita } \\
\text { USD }\end{array}$ & $\begin{array}{c}\text { Remittances } \\
\text { per Migrant } \\
\text { USD }\end{array}$ \\
\hline Bahrain & 1.6 & 1.2 & $39.1 \%$ & $1,333.3$ & $3,410.0$ \\
Kuwait & 11.7 & 2.7 & $68.8 \%$ & $4,333.3$ & $6,298.4$ \\
Oman & 5.7 & 2.7 & $28.4 \%$ & $2,111.1$ & $7,433.4$ \\
Qatar $^{4}$ & 8.9 & 1.7 & $86.5 \%$ & $5,235.2$ & $6,052.3$ \\
KSA $^{5}$ & 27.0 & 27.4 & $27.8 \%$ & $1,000.0$ & $3,544.6$ \\
UAE $^{5}$ & 8.7 & 7.5 & $70.0 \%$ & $1,160.0$ & $1,657.1$ \\
\hline Mean & 10.6 & 7.2 & $53.4 \%$ & $2,528.8$ & $4,732.6$ \\
\hline
\end{tabular}

Notes: 1. Table is based on calculations by the authors. 2. Data is from the World Development Indicators and World Bank. 3. Source is United Nations International Migrant Stock. 4. Remittance data is from Endo and Afram (2011). 5. Remittance data is from the Arab Monetary Fund online database.

Table 1 - Panel B: Remittances Outflow as a Share of Main Economic Variables (2010)

\begin{tabular}{ccccc}
\hline Countries & $\begin{array}{c}\text { Share of } \\
\text { GDP }\end{array}$ & $\begin{array}{c}\text { Share of } \\
\text { Exports }\end{array}$ & $\begin{array}{c}\text { Share of } \\
\text { Imports }\end{array}$ & Share of Consumption \\
\hline Bahrain & $7.0 \%$ & $10.2 \%$ & $14.1 \%$ & $16.5 \%$ \\
Kuwait & $8.9 \%$ & $15.7 \%$ & $35.8 \%$ & $20.0 \%$ \\
Oman & $7.8 \%$ & $23.1 \%$ & $29.3 \%$ & $20.1 \%$ \\
Qatar & $11.0 \%$ & $19.4 \%$ & $29.0 \%$ & $19.9 \%$ \\
KSA & $6.1 \%$ & $10.3 \%$ & $15.5 \%$ & $10.4 \%$ \\
UAE & $4.5 \%$ & $3.8 \%$ & $4.3 \%$ & $4.5 \%$ \\
\hline Mean & $7.5 \%$ & $13.7 \%$ & $21.3 \%$ & $15.2 \%$ \\
\hline
\end{tabular}

Notes: 1. Table is based on calculations by the authors. 2. Data is from the World Development Indicators and World Bank. 3. Data for exports, imports and consumption for Bahrain, Oman and Qatar are for 2009. 
Table 2: Summary Statistics

\begin{tabular}{|c|c|c|c|c|c|c|c|}
\hline & Statistic & $\begin{array}{l}\text { Real GDP } \\
\text { (\$million) }\end{array}$ & $\begin{array}{l}\text { Real Money } \\
\text { (\$million) }\end{array}$ & $\begin{array}{l}\text { Remittances } \\
\text { (\$million) }\end{array}$ & Deflator & $\begin{array}{l}\text { Spot } \\
\text { Oil }\end{array}$ & FFR \\
\hline \multirow{2}{*}{ Bahrain } & Mean & $310,812.69$ & $270,497.12$ & $32,491.02$ & 0.07 & 31.21 & 5.86 \\
\hline & Observations & 31.00 & 32.00 & 31.00 & 32 & 43 & 43 \\
\hline \multirow{2}{*}{ Kuwait } & Mean & $707,742.74$ & $475,691.57$ & $39,150.48$ & 0.16 & 31.21 & 5.86 \\
\hline & Observations & 39.00 & 39.00 & 34.00 & 39 & 43 & 43 \\
\hline \multirow{2}{*}{ Oman } & Mean & $342,109.06$ & $108,296.83$ & $35,887.93$ & 0.16 & 31.21 & 5.86 \\
\hline & Observations & 41.00 & 39.00 & 37.00 & 42 & 43 & 43 \\
\hline \multirow{2}{*}{ Qatar } & Mean & $509,751.04$ & $410,558.18$ & $46,141.26$ & 0.15 & 31.21 & 5.86 \\
\hline & Observations & 11.00 & 12.00 & 12.00 & 12 & 43 & 43 \\
\hline \multirow{2}{*}{ KSA } & Mean & $4,688,113.80$ & $2,222,659.84$ & $305,318.72$ & 0.12 & 31.21 & 5.86 \\
\hline & Observations & 43.00 & 43.00 & 42.00 & 43 & 43 & 43 \\
\hline \multirow{2}{*}{ UAE } & Mean & $2,777,295.47$ & $1,160,197.56$ & $103,059.88$ & 0.06 & 31.21 & 5.86 \\
\hline & Observations & 36.00 & 37.00 & 16.00 & 37 & 43 & 43 \\
\hline \multirow{2}{*}{ Total } & Mean & $1,783,295.64$ & $865,642.75$ & $108,675.76$ & 0.12 & 31.21 & 5.86 \\
\hline & Observations & 201.00 & 202.00 & 172.00 & 205 & 258 & 258 \\
\hline
\end{tabular}


Table 3: Estimation of long run money demand as in equation (2) with dummy variables

\begin{tabular}{|c|c|c|c|c|c|}
\hline VARIABLES & $\begin{array}{c}(1) \\
\text { Net Money }\end{array}$ & $\begin{array}{c}\text { (2) } \\
\text { Net Money }\end{array}$ & $\begin{array}{c}\text { (3) } \\
\text { Net Money }\end{array}$ & $\begin{array}{c}\text { (4) } \\
\text { Net Money }\end{array}$ & $\begin{array}{c}\text { (5) } \\
\text { Net Money }\end{array}$ \\
\hline Net Money(t-1) & $0.986 * * *$ & $0.982 * * *$ & $0.980 * * *$ & $0.979 * * *$ & $\mathbf{0 . 9 7 7 * * *}$ \\
\hline Net Money(t-2) & $\begin{array}{l}(0.0111) \\
-0.0106\end{array}$ & $\begin{array}{l}(0.0115) \\
-0.0122\end{array}$ & $\begin{array}{l}(0.0117) \\
-0.00888\end{array}$ & $\begin{array}{l}(0.0118) \\
-0.0101\end{array}$ & $\begin{array}{l}(0.0124) \\
-0.0105\end{array}$ \\
\hline GDP Growth & $\begin{array}{c}(0.00817) \\
\mathbf{1 . 0 2 8}^{* * * *} \\
(0.0104)\end{array}$ & $\begin{array}{c}(0.00826) \\
\mathbf{1 . 0 2 6}^{* * * *} \\
(0.0105)\end{array}$ & $\begin{array}{c}(0.00816) \\
\mathbf{1 . 0 2 4} * * * \\
(0.0106)\end{array}$ & $\begin{array}{c}(0.00842) \\
\left.\mathbf{1 . 0 2 3}_{* * *}\right) \\
(0.0107)\end{array}$ & $\begin{array}{c}(0.00851) \\
\mathbf{1 . 0 2 3}_{* * *} * \\
(0.0107)\end{array}$ \\
\hline$\Delta \mathrm{FFR}$ & $\begin{array}{c}\mathbf{0 . 0 3 7 0} * * * * \\
(0.00621)\end{array}$ & $\begin{array}{c}- \\
\mathbf{0 . 0 3 6 3} * * * \\
(0.00622)\end{array}$ & $\begin{array}{c}\mathbf{0 . 0 4 2 3} * * * \\
(0.00704)\end{array}$ & $\begin{array}{c}- \\
\mathbf{0 . 0 4 1 0} * * * * \\
(0.00737)\end{array}$ & $\begin{array}{c}- \\
\mathbf{0 . 0 4 1 8} * * * * \\
(0.00753)\end{array}$ \\
\hline $\begin{array}{l}\text { Volcker years (1979- } \\
\text { 1982) }\end{array}$ & & $\begin{array}{c}-0.0521 \\
(0.0453)\end{array}$ & & $\begin{array}{c}-0.0289 \\
(0.0492)\end{array}$ & $\begin{array}{c}-0.0266 \\
(0.0496)\end{array}$ \\
\hline Recession Dates & & & $\begin{array}{l}-0.0507 \\
(0.0328)\end{array}$ & $\begin{array}{c}-0.0423 \\
(0.0358)\end{array}$ & $\begin{array}{c}-0.0451 \\
(0.0364)\end{array}$ \\
\hline $\mathrm{GDP} \times \Delta \mathrm{FFR}$ & & & & & $\begin{array}{c}0.00255 \\
(0.00430)\end{array}$ \\
\hline Constant & $\begin{array}{l}0.666^{* *} \\
(0.271)\end{array}$ & $\begin{array}{c}0.811^{* * * *} \\
(0.298)\end{array}$ & $\begin{array}{c}0.788 * * * \\
(0.280)\end{array}$ & $\begin{array}{c}0.848^{* * * *} \\
(0.299)\end{array}$ & $\begin{array}{c}0.912 * * * \\
(0.319)\end{array}$ \\
\hline Obser & 154 & 154 & 154 & 154 & 154 \\
\hline Number of code & 6 & 6 & 6 & 6 & 6 \\
\hline
\end{tabular}

Notes: The dependent variable is Real money minus remittances (Net Money). Using Arellano and Bover (1995) and Blundell and Bond (1998) linear dynamic panel-data estimation, the data cover the period 1970-2012. The independent variables are GDP growth, the change in the Federal Funds rate (FFR), a dummy for the Volcker Experiment variable which is equal to one for the years 19791982, a dummy variable for the recession periods in the U.S. as identified by NBER. It is equal to one for the recession date. An interactive term between FFR and GDP growth is added. Standard errors are in parentheses: $* * * p<0.01, * * p<0.05,{ }^{*} p<0.1$ 
Table 4: Estimation of long run money demand as in equation (2) with subsamples

\begin{tabular}{lccc}
\hline & $\begin{array}{c}(1) \\
\text { Pre-Volcker } \\
\text { Net Money }\end{array}$ & $\begin{array}{c}(2) \\
\text { Post-Volcker } \\
\text { Net Money }\end{array}$ & $\begin{array}{c}(3) \\
\text { Oil Boom } \\
\text { Net Money }\end{array}$ \\
\hline Net Money(t-1) & $\mathbf{0 . 9 9 8 * * *}$ & $\mathbf{0 . 9 7 1 * * *}$ & $\mathbf{0 . 9 9 1 * * * *}$ \\
& $(0.0271)$ & $(0.0131)$ & $(0.0427)$ \\
Net Money(t-2) & -0.0147 & 0.0133 & $0.0546^{* * *}$ \\
GDP Growth & $(0.0165)$ & $(0.00979)$ & $(0.0203)$ \\
& $\mathbf{1 . 0 6 4} * * *$ & $\mathbf{0 . 9 9 9 * * *}$ & $\mathbf{1 . 0 9 1} * * *$ \\
FFR & $(0.0244)$ & $(0.0109)$ & $(0.0186)$ \\
& $\mathbf{- 0 . 0 5 3 4 * * *}$ & $\mathbf{- 0 . 0 2 5 9 * * *}$ & $\mathbf{- 0 . 0 2 4 5 *}$ \\
Constant & $(0.0130)$ & $(0.00681)$ & $(0.0141)$ \\
& 0.544 & 0.415 & $-1.174^{*}$ \\
Observations & $(0.639)$ & $(0.427)$ & $(0.692)$ \\
Number of code & 39 & & \\
\hline
\end{tabular}

Notes: The dependent variable is Real money minus remittances (Net Money). This is the result of the money demand equations (2) using Arellano and Bover (1995) and Blundell and Bond (1998) linear dynamic panel-data estimation. The independent variables are GDP growth, the change in the Federal Funds rate (FFR). Here instead of introducing dummy variables to control for the Volcker experience we split the data into two subsamples: 1970-1979 for the pre-Volcker experiment (Pre-Volcker), and 1982-2012 for the rest of the sample (Post-Volcker). As for the Oil Boom the sample is confined to the period 2002-2009 during which the price of oil maintained high levels. Standard errors are in parentheses: $* * * \mathrm{p}<0.01, * * \mathrm{p}<0.05, * \mathrm{p}<0.1$ 


\section{Endnotes}

${ }^{1}$ GCC countries are: Bahrain, Qatar, Oman, Kuwait, Kingdom of Saudi Arabia (KSA), and the United Arab Emirates (UAE).

${ }^{2}$ Qatar and the United Arab Emirates (UAE) do not report remittances data to the World Bank. However, Endo and Afram (2011) report that remittance outflows figures from Qatar Central Bank to be around 9 billion USD in 2009, while the Arab Monetary Fund online database reveal that remittance outflows from the UAE was about 8 billion USD in 2007. Moreover, the average remittance outflows for the 1970 - 2008 period surpassed 1billion USD in all GCC countries except for Bahrain (Naufal and Vargas - Silva, 2010).

${ }^{3}$ The correlation coefficient between FFR and oil price is -0.43 .

${ }^{4}$ The World Bank staff estimates are based on the International Monetary Fund's Balance of Payments Statistics Yearbook 2011.

5 Source is the Human Development Report (2009) at https://mobiledevelopmentintelligence.com/metrics/123

${ }^{6}$ The proportion of foreign workers to the total population is even higher when only looking at the labor force (See Ann Colton (2010) for more details).

7 The six GCC countries produced around $21 \%$ of the world's crude oil in 2009 (The share was calculated by the authors from the Organization of the Petroleum Exporting Countries (OPEC) Annual Statistics Bulletin 2009).

${ }^{8}$ A recent regulation restricts the numbers of years of residency to 6 for most blue-collar workers.

${ }^{9}$ For more information on the migration and remittance flows in the GCC countries refer to Naufal and Genc (2012). 
${ }^{10}$ Adams (2009) refers to this region as the third most important labor - receiving region in the world only behind North America and Europe.

${ }^{11}$ Higher oil prices leads to higher income in the GCC (Kandil and Morsy, 2012).

${ }^{12}$ Empirically, Al-Raisi, Pattanaik, and Al Raisi (2007) do not find evidence for the transmission of monetary policy rates to retail market rates for Oman. The authors attribute this weakness in transmission to "immature" financial markets. On the other hand, Espinoza and Prasad (2012) and Bova (2012) find that the interest rate parity can be achieved in the long run between the GCC countries and the U.S. Our study also considers the long run.

${ }^{13}$ Thus, theoretically speaking, assume that the uncovered interest rate parity can be expressed by $\left[(1+i)=\frac{s_{t}^{e}}{s}\left(i^{*}\right)\right]$ where $i\left(i^{*}\right)$ stands for the GCC (US) interest rate. While $s$ represents the current spot exchange rate, $s_{\tau}^{e}$ is the expected future spot exchange rate, $\tau$ periods from now. In other words, the returns on domestic currency- denominated and foreign currency- denominated assets should be equal, assuming the same risk. One can simplify this formula as $i=i^{*}+\frac{\Delta s_{t}^{e}}{s}$ where the $\Delta$ represents change in the variable. The second term on the right hand side is the expected depreciation of the domestic currency. Then the interest rate differential is $i-i^{*}=\frac{\Delta s_{\tau}^{e}}{s}$. In other words, the interest rate differential equals the expected rate of the depreciation of the domestic currency. However, due to the peg between the domestic currencies in the GCC and the US dollar, the right hand side of the above expression is zero because the fixed rate remains in place for the foreseeable future. That is why, domestic (GCC) and foreign (US) interest rates must be equal.

${ }^{14}$ The variables are tested for the existence of unit root in levels and first differences via a number of conventional tests. In short, they are found to be non-stationary in levels and stationary in first differences. The results are not reported here but available from the authors.

${ }^{15}$ The Pedroni Cointegration tests are available from the authors. 
${ }^{16} \mathrm{~A}$ Hausman test for random vs. fixed effects is conducted, yielding a value of 0 for the $\chi^{2}$ with 2 degrees of freedom. Its p-value is unity. Thus, as the null hypothesis of "individual effects are correlated with the independent variables" could not be rejected, we confirm the usage of the fixed effects model.

${ }^{17}$ One of the concerns in this type of estimation is the potential endogeneity problem, especially with respect to the real income variable. To tackle this problem, we estimated a dynamic OLS (DOLS) à la Stock and Watson (1993). The DOLS estimator is consistent with a common stochastic trend between the dependent and the explanatory variable(s) even if the explanatory variable(s) is endogenous. The results remain qualitatively identical to the ones reported here using a GMM dynamic panel data estimation. 